\title{
The Irish Material in the Stowe Missal Revisited ${ }^{*}$
}

\author{
Lars B. Nooij
}

\begin{abstract}
This article explores the composition history of the Stowe Missal in order to establish when and where the Irish language material contained therein was added to the manuscript. It is argued that the Stowe Missal was likely copied in early ninth-century Tallaght and that most of its Irish sections were added by the manuscript's original scribe.
\end{abstract}

Keywords: Stowe Missal, dating, provenance, palaeography, codicology, Old Irish language

Lars B. Nooij

Department of Early Irish Studies, Maynooth University

lars.nooij.2017@mumail.ie

When I joined Professor David Stifter's Chronologicon Hibernicum (ChronHib) research project, I never imagined that I would end up working on an ancient Irish missal. Truth be told, I do not think David ever thought I would either. Nonetheless, as may be seen from the present article, that is exactly what I ended up doing.

The ChronHib project aims to date linguistic variation and change within the Irish language during the Old Irish period, roughly speaking between 650 and $900 \mathrm{AD}$. In order to do so, we are assembling a searchable corpus of Irish texts from this period, and part of this work involves harmonising existing databases to a common standard. It is precisely that type of work that first introduced me to the Stowe Missal. The nature of my task was simple: add headwords (i.e. more or less the dictionary form of a word) to all the words of the Stowe Missal's Old Irish Tract on the Mass in Elliott Lash's POMIC database. ${ }^{I}$ In the process, I naturally

\footnotetext{
- This article is based on a prize-winning paper, which was awarded the Mícheál Ó Cléirigh Prize for the best graduate paper submitted to the Irish Conference of Medievalists in 2017. The present work was undertaken as part of the research project Chronologicon Hibernicum (Chron$\mathrm{Hib}$ ). The research on ChronHib has received funding from the European Research Council (ERC) under the European Union's Horizon 2020 research and innovation programme (grant agreement No. 647351).

${ }^{1}$ Elliott Lash, The parsed Old and Middle Irish corpus (POMIC): Version o.r. (2014), (available online at: https://www.dias.ie/celt/celt-publications-2/celt-the-parsed-old-and-middle-irish-corpus-pomic/), accessed Is. $4 \cdot 2018$.
}

DOI 10.1484/J.PERIT.5.118487

Peritia 29 (2018) 109-101 (c) Medieval Academy of Ireland \& Brepols Publishers 
looked up the various editions that existed of the Stowe Missal Tract. ${ }^{2}$ This article should therefore be seen as the direct result of me getting severely side-tracked.

In this publication, I hope to address a number of issues concerning the Stowe Missal manuscript in relation to the Irish material found therein. In particular, I wish to offer some thoughts as to when, where and by whom these Irish elements were added to the manuscript. And in order to do so, I find it necessary to take a position in the debate on the dating, place of origin and the various hands found in the Stowe Missal. As we will soon see, these issues are all very much interconnected.

\section{The Manuscript and its Contents}

The Stowe Missal is usually dated to the turn of the ninth century. It is therefore one of the earliest and certainly the most direct surviving witness to the liturgy of early medieval Ireland and has, as such, attracted the attention of church historians for over a century. It is also of interest to linguists, as it contains a number of short but complete prose texts in the Old Irish language, without any great admixture of Latin. Since most of our contemporary sources of Old Irish consist of brief glosses on Latin texts, the Stowe Missal is a significant source, in spite of the brevity of its Irish-language material.

The Missal is a remarkably small manuscript, consisting - in its present form of 67 leaves, each measuring about i 4 by in centimetres. The leaves are gathered in five highly irregular gatherings. The smallest contains io leaves, whereas the largest - at 18 leaves - contains almost double that amount. The manuscript bears witness to an extended and complex period of composition: in total, eleven leaves have been added to the second and third gatherings by a later scribe, who calls himself Móel Caích, and who also wrote extensively in space originally left blank and in rasura. Moreover, the entire first gathering did not originally belong to the Stowe Missal, but must have had an earlier, independent existence.

This first gathering contains extracts from the Gospel of St John and ends with an image of the Saint himself, untypically found at the back, rather than in front of the Gospel. The second and third gatherings consist of the Ordinary and Canon of the Mass, as well as three special, votive Masses. The final page of the third gathering was originally left blank, but Móel Caích used the space to add an incipit to the Order of Baptism, which properly begins on the following page. The fourth and fifth gatherings contain the aforementioned Order of Baptism, the Commun-

2 The most comprehensive edition is George F. Warner, The Stowe Missal: MS D. II. 3 in the library of the Royal Irish Academy, Dublin, 2 vols, Henry Bradshaw Society Publications 31 , 32 (London 1906 \&I915). For the Irish material, see: Whitley Stokes \& John Strachan (eds), Thesaurus palaeohibernicus: a collection of Old-Irish glosses, scholia, prose and verse, 2 vols (Cambridge I90I \&I903) ii, 250-55. 
ion of the Newly Baptised, the Visitation of the Sick and the Administration of Extreme Unction, as well as the Old Irish Tract on the Mass and three charms in Old Irish. It may therefore be noted that two of the breaks between gatherings originally coincided with a change of content: both that between the first and second gatherings and that between the third and fourth.

The Irish material in the Missal consists chiefly of the Old Irish Tract on the Mass and the three charms that occupy the final leaves of the manuscript. Additionally, rubrics and glosses are found throughout the later four gatherings. Finally, one unusual Irish name, written in ogam, is found in the first gathering, where the scribe of the gospel extracts - a man who calls himself Sonid peregrinus - signs off.

\section{The Stowe Missal Scribes}

The number of scribes active in the remainder of the manuscript, beyond the first gathering, has long been somewhat uncertain. George Warner, who edited the Missal about a century ago, identified five original hands in the Latin parts, calling them Ar to A5. ${ }^{3} \mathrm{He}$ noted that these hands were very similar and believed them to belong to members of the same school, or scriptorium. Recently, however, Timothy O'Neill has argued persuasively that these hands are actually one and the same the subtle differences appear to be due to one scribe's use of differently shaped quill nibs, rather than reflecting the hands of different scribes. ${ }^{4}$ Moreover, O'Neill has added that the penwork decorations found on some of the initials - primarily, but not exclusively, in the Order of Baptism - were added by a later scribe and fit in with the style of the eleventh and twelfth centuries. ${ }^{5}$ Now might also be a good time to point out that apart from this apparently later penwork, the drawing of St John and some decorations on the opening pages of both the Missal proper and the Gospel extracts, the manuscript is entirely devoid of decoration. Taking this together with its small size, the Missal was clearly a humble and inexpensive production.

Relatively few scholars have commented on the scribe of the Old Irish Tract, beyond stating that the hand is similar to that of the original scribe of the main, Latin sections of the Missal, and that it does not appear to be any later in date. Fewer still have discussed the hand (or hands) of the three charms, but the charms themselves are generally considered to be later additions to the manuscript. The main reasoning for this is presumably simply that they are found on the final page and do not have as strong a connection - in terms of content - to the Missal proper as the other parts of the text. Howeyer, Jacqueline Borsje has pointed out

3 Warner, Stowe Missal, ii, xii-xiv.

4 Timothy O'Neill, 'Quills, inks and vellums', in Bernadette Cunningham \& Siobhán Fitzpatrick (eds), Treasures of the Royal Irish Academy Library (Dublin 2009) 45-49: 46.

s O’Neill, 'Quills, inks and vellums', 46. 
that the first charm quotes the Gospel of St John, that St Ibor - who is also included in a litany in the original Missal itself - is also invoked and that these charms are definitely open to a Christian interpretation. ${ }^{6}$ Truth be told, I do not see any reason per se to assign the charms to a later period than the Tract.

As to the Irish rubrics and glosses found in the Latin sections of the Missal, it is clear that most were added by the main interpolator, Móel Caích, who otherwise writes in Latin and has a very distinct hand. Two rubrics found in the fourth gathering have been added by yet another, presumably later, scribe.

Excluding the gospel extracts and Móel Caích's additions for the moment, the script of the original Latin sections has variously been described as a rather large minuscule, or a semi-majuscule, or even a plain majuscule script. I am certainly no expert on palaeography, but, if pressed, I would prefer to call it a rather large, carefully wrought minuscule myself. But this comes with one very significant exception, for the letter $\mathrm{R}$ is consistently written as a majuscule. The Irish sections, on the other hand, are written in a much smaller, rather irregular and perhaps even rough script. This striking discrepancy can reasonably be explained as reflecting the different purposes of the various sections. The Missal proper, the Order of Baptism and the other large-script sections are all intended for direct consultation by the priest during religious services, in which reading conditions might not be optimal. And as we are dealing with a very small manuscript to start with, legibility could have been a very real issue. The Irish Tract, on the other hand, is a theological text, presumably intended for private study.

Looking more closely at the script of the original Latin scribe of the Missal and comparing this to the hand of the Old Irish Tract, I am increasingly convinced that they are actually one and the same, as Gwynn argued about a century ago. ${ }^{7}$ Much like O'Neill explained the differences between the Latin hands as being due to a difference in quill nib size, rather than due to the activities of different scribes, so in this case the subtle and sometimes not so subtle differences are to be explained as being due to a difference in care. The similarities are nonetheless strong. In both cases, the script is not as rounded as commonly associated with Insular script, but is distinctly angular. Moreover, the letter $\mathrm{R}$ is consistently written as a majuscule in both sections. In general, the execution of the letters is very similar, which may especially be noted for the letters $b, l, f$ and $o$. Additionally, the resemblance between the script of the Tract and that of the Latin glosses on fol. $20^{\mathrm{v}}-$ which are almost certainly by the original scribe himself, writing in small script - is strong.

A further comparison of the script of the Tract with that of the three charms yields similar results. The script is distinctly angular throughout and in each of

\footnotetext{
${ }^{6}$ Jacqueline Borsje, 'The second spell in the Stowe Missal', in Cathinka Hambro \& Lars Ivar Widarøe (eds), Lochlann: Festskrift til Jan Erik Rekdal på 6o-ärsdagen (Oslo 2013) 12-26.

7 E. J. Gwynn, 'The Stowe Missal', Irish Church Quarterly 9 (1916) I19-33: 13I-33.
} 
the three charms the letter $\mathrm{R}$ is written as a majuscule. In general, the script is very much alike. There are, however, some superficial differences between the scripts of the three charms themselves. These differences are in the colour of the ink, the size of the letters and the sharpness of the letters. The latter can presumably be explained as, again, being a matter of nib size. As we already know that this scribe did not consistently maintain his quills to any one standard when he was writing the Latin main text, this should come as no great surprise. As to the size of the letters and the ink, these inconsistencies can readily be explained by arguing that the charms were copied into the manuscript at different moments. Looking at my own diary, it is all too obvious that the exact size of my own handwriting may differ quite considerably from one time to another - even when continuing to write a new entry right underneath the preceding one. As to the ink, this would simply be whatever he had available, which might not always be exactly the same.

In conclusion - on this particular point - it would therefore seem that we are dealing with the following scribes and stages of composition:

I. The Original Scribe $=$ the Missal Proper and the Old Irish Tract on the Mass

2. The Original Scribe $=$ the three Irish Charms

3. Móel Caích $=$ the major interpolations, including most of the Irish rubrics

4. Later scribe $(s)=$ penwork decorations and two Irish rubrics

The crucial bit here, to my own interests at least, is that nearly all of the Irish material was added to the manuscript very early on and largely by the original scribe. This means that, if we can date and localise the origins of the manuscript, we also discover when and where this Irish material was written down in its present form.

\section{Dating the Stowe Missal}

This, then, brings us to the dating itself. The Stowe Missal has traditionally been dated rather narrowly to the period 792 to $8 \mathrm{I} 2 \mathrm{AD},{ }^{8}$ or sometimes yet more exactly to 792 to $803 \mathrm{AD}$. $^{9}$ This dating is based on the fact that St Máel Rúain is included as the most recent saint by far in a litany in the hand of the original scribe. As Máel Rúain died on the seventh of July 792 , the manuscript can hardly have been written before that time. The mention of Máel Rúain has also traditionally been taken as

8 This dating originated with Warner's edition, see: Warner, Stowe Missal, ii, xxii-xxxix.

9 F. J. Byrne, 'The Stowe Missal', in Liam de Paor (ed), Great books of Ireland. Thomas Davis Lectures (Dublin \& London 1967) 38 -50: $48-49$. 
a sign that the manuscript was copied at the monastery of Tallaght, in the Dublin area, founded by Máel Rúain in the late eighth century. The lack of any mention of his direct successors in either the abbacy or the bishopric (St Airendán, d. 803 and St Eochaid, d. 812 respectively) in the Missal was then taken as indicative that the manuscript was written while they were still alive.

Obviously, this is not a very strong argument for a terminus ante quem and it has certainly come under fire, especially from those who question whether the manuscript was written at Tallaght at all. Before turning to the issue of place, it should be noted that palaeographers now tend to agree that the original scribe and Móel Caích both wrote before about $850 \mathrm{AD}$, citing that major developments which took place in the script after that time are absent in their writing. ${ }^{10}$

Although it is clear that the traditional terminus ante quem cannot be maintained, it may be possible to bring the terminus post quem forward from 792 to the very end of the eighth century. As I mentioned before, the original scribe added some Latin glosses to the Latin main text on fol. $20^{\mathrm{v}}$. The main text here is the Creed, and amongst other things the glosses include the infamous filioque clause. According to Aidan Breen, the glosses represent modifications to the Creed composed by Paulinus II of Aquileia in 796/797 and adopted in the Carolingian empire at the council of Aachen in $798 .{ }^{.1}$ If this identification is correct, it shows both the speed with which this innovation was adopted in Ireland and allows us to either bring forward the terminus post quem to 798 , or, at the very least, establish that the manuscript was still being worked on by the original scribe at that time.

\section{Place of Origin}

Moving on then, there are two main theories as to the place of origin of the Stowe Missal. What is certain is that the manuscript was at Lorrha (in Lower Ormond, in Munster) by about I027-IO33 AD. At that time a shrine, or cumtach, was produced to encase the manuscript as a relic. Inscriptions on the original face of this shrine securely establish both the time and the place of its making, as Pádraig Ó Riain has shown. ${ }^{12}$ The manuscript was still at Lorrha when the shrine was refurbished (and new inscriptions were added) a few centuries later, ${ }^{13}$ and

to David Dumville, 'Félire Oengusso: problems of dating a monument of Old Irish', Éigse 33 (2002) 19-48: 43. For a more general description, see Timothy O'Neill, The Irish hand: scribes and their manuscripts from the earliest times (2nd ed. Cork 2014).

"Aidan Breen, 'The text of the Constantinopolitan Creed in the Stowe Missal', Proceedings of the Royal Irish Academy C 90 (1990) I07-2I: 118-2I.

${ }^{12}$ Pádraig Ó Riain, 'The shrine of the Stowe Missal: redated', Proceedings of the Royal Irish Academy $C_{91}$ (1991) 285-95: 287-94.

${ }_{13}$ T. F. O'Rahilly, 'The history of the Stowe Missal', Ériu ro (1926-1928) 95-109: 97. 
indeed, when the manuscript was rediscovered in the eighteenth century it was claimed to have been found during restoration work, hidden away in the walls of Lackeen Castle, very near to Lorrha Abbey still. ${ }^{14}$ The association with Stowe in Buckinghamshire comes merely from its having been part of the library of the Marquess of Buckingham at Stowe House for a few decades during the early nineteenth century.

As mentioned, the traditional view on the provenance of the Stowe Missal is that it was copied at Tallaght during the late eighth, or early ninth century. The interpolator, Móel Caích, is taken to have been active shortly thereafter and his alterations are seen to reflect a change of location - that is to say, they are regarded as adaptations to a different, local liturgical practice. As the manuscript next turns up in Lorrha, this is assumed to have been its destination. The alternative view is that, since there is no compelling evidence that the manuscript was ever anywhere but in Lorrha, this is also the place where it was originally written.

Proponents of the latter tend to focus on the argument that St Máel Rúain was so famous that he might well have been venerated at other locations than Tallaght and that his inclusion in the litany is no more than suggestive of a Tallaght provenance. ${ }^{\text {Is }}$ However, it should be noted that there is no conclusive text-internal evidence for a Lorrha provenance, either. It therefore seems appropriate to provide an overview of the arguments.

These are the arguments in favour of a Lorrha provenance:

I. There is no conclusive text-internal evidence for the provenance of the manuscript.

2. The inscriptions on the shrine prove that the manuscript was at Lorrha from at least the early eleventh century onwards.

3. In addition to this, it has been suggested that the large, angular script of the Latin parts of the Missal reflects some kind of North Tipperary style; ${ }^{16}$ however, this connection is only apparent for (part of) the Gospel of St John, the script of which is similar to that of the Book of Dimma St John. Unfortunately, the earliest origin of both the Stowe St John and the Book of Dimma appears to have been distinct from that of the remainder of these manuscripts. The arguments in favour of a Tallaght provenance are more extensive:

${ }^{14}$ O'Rahilly, 'The history of the Stowe Missal', io - 04.

is e.g. John Ryan, 'The Mass in the early Irish Church', Studies 50 (I96I) 371-84: 376.

${ }^{16}$ Ó Riain, 'The shrine of the Stowe Missal', 295, citing William O'Sullivan. See now W. O'Sullivan, 'Manuscripts and palaeography', in Dáibhí Ó Cróinín (ed), A New History of Ireland I, prebistoric and early Ireland (Oxford 2005) 5II-48: 538 n. 139 . 
I. Máel Rúain of Tallaght is mentioned in a litany of saints in the original part of the Missal. ${ }^{17}$ On its own this is a weak argument, but it is reinforced by the following matters:

a. Máel Rúain has been consciously added to this litany, which otherwise consists of earlier saints.

b. Máel Rúain is one of only a handful of saints in the litany (along with, for example, St Patrick and St Peter) who is awarded the special prominence of having his name written with a capital letter.

2. St Ruadán, founder of Lorrha, is not included in the original litany, although it may be noted that his name is found in another litany, added by Móel Caích. Had the manuscript originated in Lorrha, one would expect St Ruadán to have been mentioned with distinction.

3. The saints in the original litany show a Leinster bias; whereas those in Móel Caích's litany mainly derive from central and southern Ireland. ${ }^{18}$ The former accords well with a Tallaght origin, but conflicts with one in Lorrha.

4. John Hennig, moreover, suggested a link between the Martyrology of Tallaght, which is usually thought to have at least had a Tallaght phase, or been influenced by Tallaght sources, and the Stowe Missal. ${ }^{19}$ It has to be said that his primary claim, namely that parts of the Martyrology and the Missal (or its archetype) were designed to be used together, is very much open to debate. However, there is another close similarity between the two texts:

a. The liturgical year starts at Christmas in both the Missal and the Martyrology. ${ }^{20}$

5. There is also a similarity between the Stowe Missal and the tract known as 'The Teaching of Máel Rúain':

a. The same eight, chief festivals appear to be celebrated in both the Missal and the Rule. ${ }^{21}$

6. Westley Follett also notes that a move from Tallaght to Lorrha would parallel similar proposed moves of the exemplar of the Martyrology of Tallaght and perhaps the Tallaght Memoir from Tallaght to Lower Ormond within the same timeframe. ${ }^{22}$

${ }_{17}$ This is on fol. $33^{\text {r }}$; for a discussion, see Warner, Stowe Missal, ii, xxvi-xxiv.

${ }_{18}$ Thomas O'Loughlin, Celtic theology: humanity, world and God in early Irish writings (New York \& London 2000) I40; also Sven Meeder, 'The early Irish Stowe Missal's destination and function', Early Medieval Europe I3 (2005) 179-94: I8I.

19 John Hennig, 'The function of the Martyrology of 'Tallaght', Medieval Studies 26 (1964) 315-28: 320-28.

20 Hennig, 'The Martyrology of Tallaght', 323 .

${ }^{21}$ Westley Follett, Céli Dé in Ireland: monastic writing and identity in the early Middle Ages (Rochester NY \& Woodbridge UK 2006) 133.

${ }^{22}$ Follett, Céli Dé in Ireland, 135 . 
A final, possible sign of Tallaght influence comes from an unexpected source and is therefore harder to interpret. Móel Caích, in his litany, includes St Scíath, a lesser-known, female saint from the south of Ireland, who is also known from the Martyrology of Tallaght and the Féilire Óengusso, where her feast-day is listed. In the Martyrology of Tallaght, the arrival of her relics at Tallaght is also commemorated, attesting to her veneration at the monastery. ${ }^{23}$

Taking all this together, I would say that although there is no conclusive evidence as to the provenance of the Stowe Missal, there are persistent, text-internal hints in favour of Tallaght, which makes a Lorrha origin appear less likely. Móel Caích, however, with his alterations, differing script and focus on central-southern Irish saints, may very well have been from Lower Ormond, or even from Lorrha itself. His mention of St Sciath, if this is indeed to be seen as a link to Tallaght, may well be due simply to his use of a Tallaght source. He did, after all, have access to at least one book that appears to be from Tallaght: the Stowe Missal itself.

\section{Conclusion}

Before summing up the findings, I would merely like to add that to some extent this paper is - I hope - but the beginning. Over the next few years, as the project progresses, I hope to do a linguistic study of the Irish forms found in the Stowe Missal. For although we may have a fair idea of when and where the Irish material was added to the manuscript, we do not yet know much at all about when it was originally composed. Especially in the case of the Tract on the Mass, it is clear that the Stowe Missal version is a copy of some underlying original. Hopefully, a linguistic study will be able to shed some light on the nature of this yet earlier stage.

Finally, then, in conclusion, it may be stated that the Old Irish Tract on the Mass was copied into the Stowe Missal by the manuscript's original scribe, likely at Tallaght at the beginning of the ninth century. The manuscript was then presumably put to practical use by the scribe himself, who seems to have been an officiating priest - and likely an itinerant one, given the eminently portable nature of the Missal. Over time he added the three Irish charms, perhaps in the course of his travels. Afterwards, but still within the first half of the ninth century, the manuscript was acquired by another priest named Móel Caích, who heavily adjusted it to suit his own liturgical practices and, in the process, added some Old Irish rubrics and glosses to the Latin sections of the Missal. At this stage, the manuscript appears to have been in Lorrha. At some point, a scribe wrote two further Old Irish rubrics into the text and some penwork decorations were added. The manuscript then remained at Lorrha, where - in spite of its humble origins - it acquired the status of a relic and was eventually enshrined in the early eleventh century. The rest, as they say, is history.

${ }^{23}$ Warner, The Stowe Missal, ii, xxvi; also Follett, Céli Dé in Ireland, 135.

(C) BREPOLS PUBLISHERS

THIS DOCUMENT MAY BE PRINTED FOR PRIVATE USE ONIY. TI MAY NOT BE DISTRIBUTTFD WITHOUT PERMISSION OF THE PUBL.ISHER 